\title{
Post-nesting migrations of Galápagos green turtles Chelonia mydas in relation to oceanographic conditions: integrating satellite telemetry with remotely sensed ocean data
}

\author{
Jeffrey A. Seminoff ${ }^{1, *}$, Patricia Zárate ${ }^{2}$, Michael Coyne ${ }^{3}$, David G. Foley ${ }^{4,5}$, \\ Denise Parker ${ }^{1}$, Boyd N. Lyon ${ }^{6, \mp}$, Peter H. Dutton ${ }^{1}$ \\ ${ }^{1}$ NOAA-National Marine Fisheries Service, Southwest Fisheries Science Center, 8604 La Jolla Shores Dr., La Jolla, \\ California 92037, USA \\ ${ }^{2}$ Charles Darwin Research Station, Puerto Ayora, Santa Cruz, Galápagos Islands, Ecuador \\ ${ }^{3}$ SEATURTLE.ORG, 1 Southampton Place, Durham, North Carolina 27705, USA \\ ${ }^{4}$ Joint Institute for Marine and Atmospheric Research, University of Hawai'i at Manoa, 1000 Pope Road, Honolulu, \\ Hawai'i 96822, USA \\ ${ }^{5}$ NOAA Fisheries, Environmental Research Division, Southwest Fisheries Science Center, 1352 Lighthouse Avenue, \\ Pacific Grove, California 93950-2097, USA \\ ${ }^{6}$ Department of Biology, University of Central Florida, PO Box 162368, Orlando, Florida 32816, USA
}

\begin{abstract}
Post-nesting movements of 12 green turtles from the Galápagos Islands (Ecuador) were tracked with satellite telemetry during the 2003 and 2005 nesting seasons. To illuminate potential environmental influences on turtle movements we compared tracks with a variety of remotely sensed oceanographic variables including sea surface temperature (SST), SST front probability, surface height anomaly, surface current, and surface chlorophyll a concentration. Three distinct post-nesting migratory strategies were observed, including oceanic migration to Central America (Type A1 movements, $\mathrm{n}=3$ ), residency within the Galápagos (Type A2 movements, $\mathrm{n}=2$ ), and movement into oceanic waters southwest of the Galápagos (Type B movements, $\mathrm{n}=7$ ). Two turtles migrating to Central America reached neritic foraging areas in Nicaragua and Panama that were 1500 and $1542 \mathrm{~km}$, respectively, from their nesting sites, and one resident turtle established a foraging home range $75 \mathrm{~km}$ from its final nesting site. Oceanic movements occurred in waters with a mean SST of $26.5^{\circ} \mathrm{C}$ and mean surface chlorophyll a concentration of $0.18 \mathrm{mg} \mathrm{m}^{-3}$, whereas neritic movements were in waters with a mean SST of $24.3^{\circ} \mathrm{C}$ and mean surface chlorophyll a concentration of $0.47 \mathrm{mg} \mathrm{m}^{-3}$. All turtles accessed SST frontal zones at a greater rate than their availability, and at least 2 turtles conducted movements in the oceanic zone that were indicative of foraging activity. This is the first report of migratory corridors for Galápagos green turtles, confirming prior flipper tagging data that show that the Galápagos is a source rookery for green turtles in coastal areas of Central America. The high proportion of green turtles departing the Galápagos (83\%) indicates that marine fisheries bycatch and directed hunting on this stock outside the Galápagos may impact this population more than previously believed, and underscores the need for multi-national conservation efforts that combat these threats.
\end{abstract}

KEY WORDS: Black turtle $\cdot$ Chelonia agassizii $\cdot$ Cheloniidae $\cdot$ Chlorophyll a $\cdot$ Eastern Tropical Pacific Ocean $\cdot$ Frontal zones $\cdot$ Migration $\cdot$ Sea surface temperature $\cdot$ Sea surface height anomaly 


\section{INTRODUCTION}

Green turtles Chelonia mydas are highly migratory and undertake complex movements through geographically disparate habitats during their life cycle (Musick \& Limpus 1997, Plotkin 2003). The periodic migration of hundreds to thousands of kilometers between breeding and foraging areas by adults is a prominent feature of their life history. The longdistance movements of green turtles were first resolved with flipper tagging (Carr et al. 1978, Alvarado \& Figueroa 1992) and more recently with genetic analyses (Bass et al. 2006, Dethmers et al. 2006). The use of satellite telemetry has expanded this understanding, revealing foraging area destinations of migrating post-nesting turtles as well as providing information on migratory routes, travel speeds, and dive behavior (Cheng 2000, Godley et al. 2002, Hays et al. 2002, Craig et al. 2004, Kennett et al. 2004, Troëng et al. 2005, Blumenthal et al. 2006). Further, because satellite telemetry yields spatio-temporal patterns of turtle distribution, the resultant migratory tracks can be integrated with remotely sensed data to elucidate the underlying oceanographic conditions that may influence sea turtle habitat use.

Understanding such factors is critical for improving management and conservation initiatives for sea turtles. While basic environmental features such as bathymetry, sea surface temperature (SST), and surface currents have been linked to sea turtle movements (Morreale et al. 1996, Hays et al. 2001, Luschi et al. 2003, Pelletier et al. 2003, Etnoyer et al. 2006), the mechanisms underlying these relationships are inadequately understood. Dynamic mesoscale processes such as SST and chlorophyll fronts - areas of interface between 2 dissimilar water masses - are known to strongly affect water column primary and secondary productivity (Olson et al. 1994, Palacios et al. 2006), and their status as prey aggregation zones suggests that they too may influence sea turtle movements. For example, juvenile loggerhead turtles Caretta caretta in the North Pacific have been shown to forage in the Kuroshio Extension Bifurcation Region during periods of high surface chlorophyll (Polovina et al. 2006); when waters become vertically stratified and surface chlorophyll levels decrease, they move farther north to the Transition Zone Chlorophyll Front region-a welldescribed biological hotspot and an important oceanic foraging destination for a variety of marine taxa (e.g. Polovina et al. 2000, 2001). Frontal zones have also been described as important foraging zones for large whales (Doniol-Valcroze et al. 2007) and commercially targeted species such as tuna and swordfish (Fiedler \& Bernard 1987, Podesta et al. 1993). Knowledge of the spatio-temporal persistence of these mesoscale fea- tures can be highly informative for developing predictive models of sea turtle habitat use; however, there is an obvious need for additional data from a variety of marine species and ocean regions to determine the efficacy of such modeling efforts.

The Eastern Tropical Pacific Ocean (ETP) is an area with complex topography and substantial spatiotemporal variability in oceanographic characteristics (Chavez et al. 1999, Fieldler 2002a). Oceanic waters in this region contain several biological hotspots, including the nutrient-enriched Galápagos plume (Palacios 2002), the shoaling thermocline of the Costa Rica Dome (Fiedler 2002b), and the Peruvian coastal upwelling region (Strub et al. 1995, 1998). Such mesoscale features can be important areas of aggregation for a variety of marine organisms (Worm et al. 2005, Pennington et al. 2006), but their persistence is dramatically impacted by the El Niño Southern Oscillation (ENSO). This 3 to 6 yr cycle within the coupled oceanatmosphere system of the tropical Pacific brings increased surface water temperatures and lower primary productivity, both of which have profound biological consequences (Chavez et al. 1999). This variability in oceanographic conditions coupled with the presence of numerous well-described biological hotspots provides an ideal opportunity to examine the effects of ocean climate on large, tractable marine species. As the ETP is a region of high use by sea turtles, this taxon is a prime candidate for commencing such studies. Satellite telemetry studies have described movements of olive ridley turtles Lepidochelys olivacea and leatherback turtles Dermochelys coriacea in relation to bathymetry in the area (Plotkin et al. 1995, Morreale et al. 1996), but so far no studies have examined turtle movements in relation to other oceanographic conditions in the ETP, although Saba et al. (2007) examined leatherback nesting biology relative to oceanography in the region.

Prominent in this area are the Galápagos Islands (hereafter referred to as the Galápagos), a 19-island archipelago located $\sim 1000 \mathrm{~km}$ from coastal Ecuador (Fig. 1). The Galápagos are among the most important nesting areas for green turtles in the ETP, and turtles are afforded protection by the $138000 \mathrm{~km}^{2}$ Galápagos Biological Reserve of Marine Resources, which regulates fishing pressures and provides marine habitat and nesting beach protection (Heylings et al. 2002). Flipper tagging programs (Green \& Ortiz-Crespo 1982, Green 1984, Zárate \& Dutton 2002) and genetic data (P. H. Dutton unpubl. data) have shown that green turtles nesting in the Galápagos move to foraging areas both within the archipelago and along the continental shelf of Central and South America. However, although Galápagos green turtles evidently cross oceanic areas to reach mainland coastal habitats, 
nothing is known about their migratory corridors, nor are there data on how these turtles are affected by oceanographic conditions. Further, with fewer than 30 long distance $(>1000 \mathrm{~km})$ tag returns of the $\sim 14000$ green turtles that have been tagged (Green 1984, Zárate \& Dutton 2002), there are sparse data on the relative importance of various coastal foraging sites for this nesting stock.

Knowledge about the oceanic movements and foraging area destinations of Galápagos green turtles can elucidate their susceptibility to human impacts such as fisheries bycatch and targeted capture and can also illuminate the areas of greatest need for conservation efforts. In the present study, we use satellite telemetry to track the post-nesting movements of green turtles from the Galápagos and compare these movement paths with a range of remotely sensed oceanic parameters. Our goals were to (1) quantify the proportion of green turtles that depart the Galápagos after nesting activity, (2) determine their migratory corridors and foraging area destinations, and (3) determine which, if any, oceanographic features influenced the movements of green turtles. Besides providing information on green turtles per se, our results will also have general relevance for the understanding of oceanographic influences on other sea turtle species in the ETP.

\section{MATERIALS AND METHODS}

Tracking data. Twelve adult female green turtles ranging from 71.6 to $96.5 \mathrm{~cm}$ curved carapace length (CCL, measured from nuchal notch to posterior-most tip of carapace; mean $=83.0 \pm 2.0 \mathrm{~cm}$ ) were fitted with satellite transmitters (Platform Transmitter Terminals; PTTs) during the 2003 ( $\mathrm{n}=4$ ) and 2005 ( $\mathrm{n}=8$ ) nesting seasons in the Galápagos Archipelago, Ecuador (Appendix 1). The turtles were equipped with PTTs prior to returning to the sea at 3 different nesting beaches: Las Salinas (Baltras Island; $\mathrm{n}=3$ ), Barahona (Isabela Island; $\mathrm{n}=$ 3), and Quinta Playa (Isabela Island; $\mathrm{n}=6$ ) (Fig. 1).

We used Telonics ST-18 (in 2003) and ST-20 (in 2005) transmitters (Mesa) that measured $6.0 \times 12.3 \times$ $2.8 \mathrm{~cm}$ in size and $276 \mathrm{~g}$ in weight ( $<1 \%$ of the approximate weight of each turtle). For the ST-18 transmitters, duty cycles (hours during which transmissions are turned on/off to maximize battery life) were $12 / 48$ for 3 of the PTTs and 24/24 for one of the PTTs. For the ST-20 transmitters, duty cycles were 24/0 for Days 1 to 45, 12/25 for Days 46 to 70 , and 6/25 for Day 71 to end of tag life. Battery life was further prolonged by the presence of a saltwater-activated switch that prevented transmissions during immersion. Transmitters were affixed to the highest point of each turtle's carapace using fiberglass cloth and polyester resin (Balazs et al. 1996) after surfaces had been cleansed of grease and debris. Each unit was oriented with the antenna to the rear, with a roll of $\operatorname{Kevlar}^{\circledR}$ attached anterior to the antenna to protect its base.

Turtle positions were determined with the Argos system, which categorized each location message received into one of 6 location classes (LC): 3, 2, 1, $0, A$, and B (Appendix 1). Argos assigns accuracy estimations of $<150 \mathrm{~m}$ for LC 3, 150 to $350 \mathrm{~m}$ for LC 2, 351 to $1000 \mathrm{~m}$ for LC 1 , and $>1000 \mathrm{~m}$ for LC 0 . No accuracy estimation is provided for LC A or LC B. However, rather than limiting our track construction to the use of LCs with optimal accuracy estimates (i.e. LC 3, 2, and 1), we instead used a series of filters that excluded biologically unreasonable results for travel speed $\left(>5 \mathrm{~km} \mathrm{~h}^{-1}\right.$ ) or indicated turning angles that did not conform to a directional track line $\left(<10^{\circ}\right)$, as this approach has been shown to maximize the utility of Argos-derived positions for wildlife tracking (M. S. Coyne et al. unpubl.).

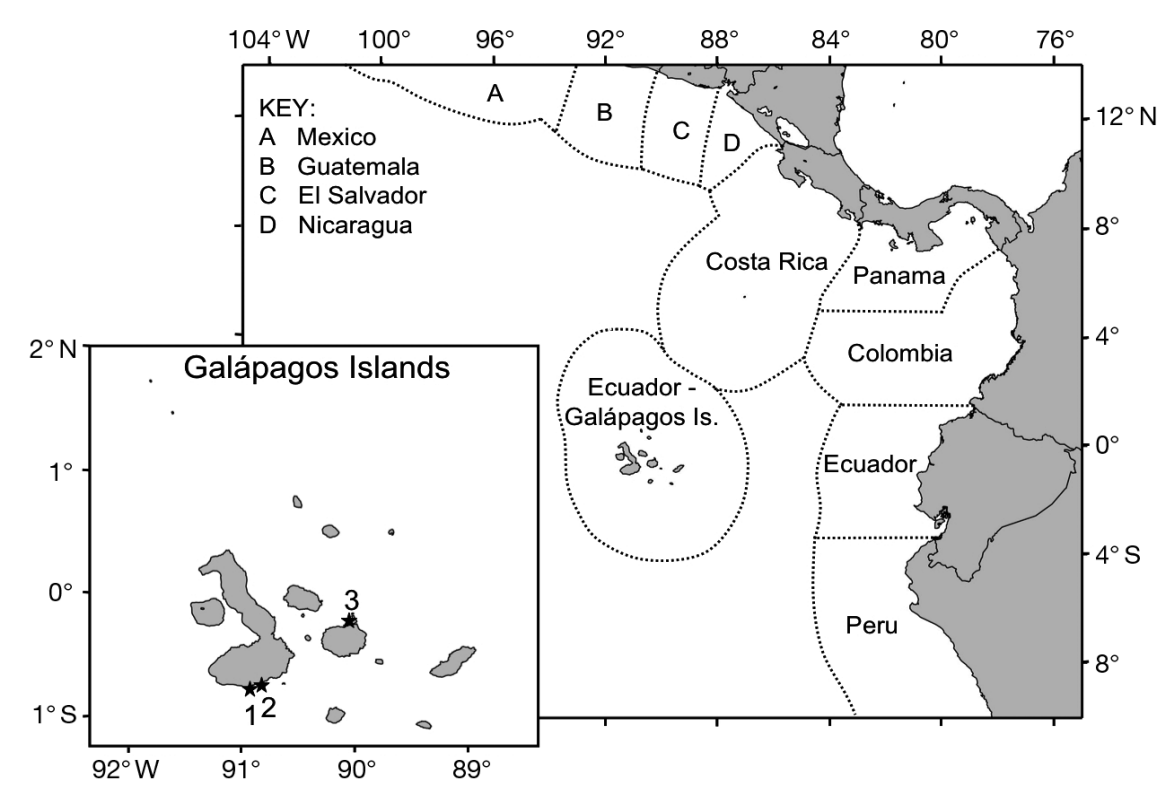

Fig. 1. Economic Exclusive Zones (EEZs) in the Eastern Tropical Pacific with inset map of the Galápagos Islands. Dashed lines indicate EEZ boundaries; «: satellite tag deployment locations - 1, Quina Playa (Isabela Island); 2, Barahona (Isabela Island); 3, Las Salinas (Baltras Island) 
The Argos locations were analyzed using Satellite Tracking and Analysis Tool (STAT) (Coyne \& Godley 2005) and were mapped using MapTool and Generic Mapping Tools (Wessel \& Smith 1991). The tracks from each turtle were partitioned based on the relationship between the time since deployment and distance from release point (i.e. displacement plot; Blumenthal et al. 2006; our Fig. 2). The curves of these displacement plots showed distinct inflections that corresponded with changes in travel speed as turtles commenced and/or completed migratory movements. Post-nesting migrations were considered to start on the day coinciding with the beginning of a positive slope lasting $>25 \mathrm{~d}$ in the displacement curve and, for turtles moving to Central America, migration was considered to have been completed on the day that the positive slope reached asymptote. A migration straightness index (MSI) was calculated for each turtle's migratory movements, based on the ratio of straight line distance between first and last oceanic Argos locations to the total oceanic track length (Luschi et al. 1998, Godley et al. 2002). We determined mean travel speed $\left(\mathrm{km} \mathrm{d}^{-1}\right)$ in each zone using the travel speeds of each successive track segment within the zone separated by $\geq 12 \mathrm{~h}$. Mean \pm SE are given unless otherwise noted.

Satellite data. We compared the tracks of each turtle with information on bathymetry, SST, SST front probability, geostrophic surface currents, sea surface height anomaly (SSHa), and surface chlorophyll a (chl a) concentration. Bathymetric values for the region were determined with the General Bathymetric Chart of the Oceans (GEBCO; www.ngdc.noaa.gov/mgg/gebco/; IOC, IHO, BODC 2003). SST data were obtained from 4 sources (Table 1), and were blended with weighted averages based on the nominal errors for each dataset. SST fronts were determined using a Frontal Probability Index (FPI; Breaker et al. 2005, Castelao et al. 2005), calculated as the fraction of days in a given $14 \mathrm{~d}$ period for which fronts are detected within each $0.05^{\circ} \times 0.05^{\circ}$ $(\sim 5.5 \times 5.5 \mathrm{~km})$ cell in the study area (delineated by $13^{\circ} \mathrm{N}, 13^{\circ} \mathrm{S}, 102^{\circ} \mathrm{W}$, and the coast of Central and South America). The FPI used herein is derived through a combination of gradient threshold tests and along-front feature tracking algorithms (e.g.
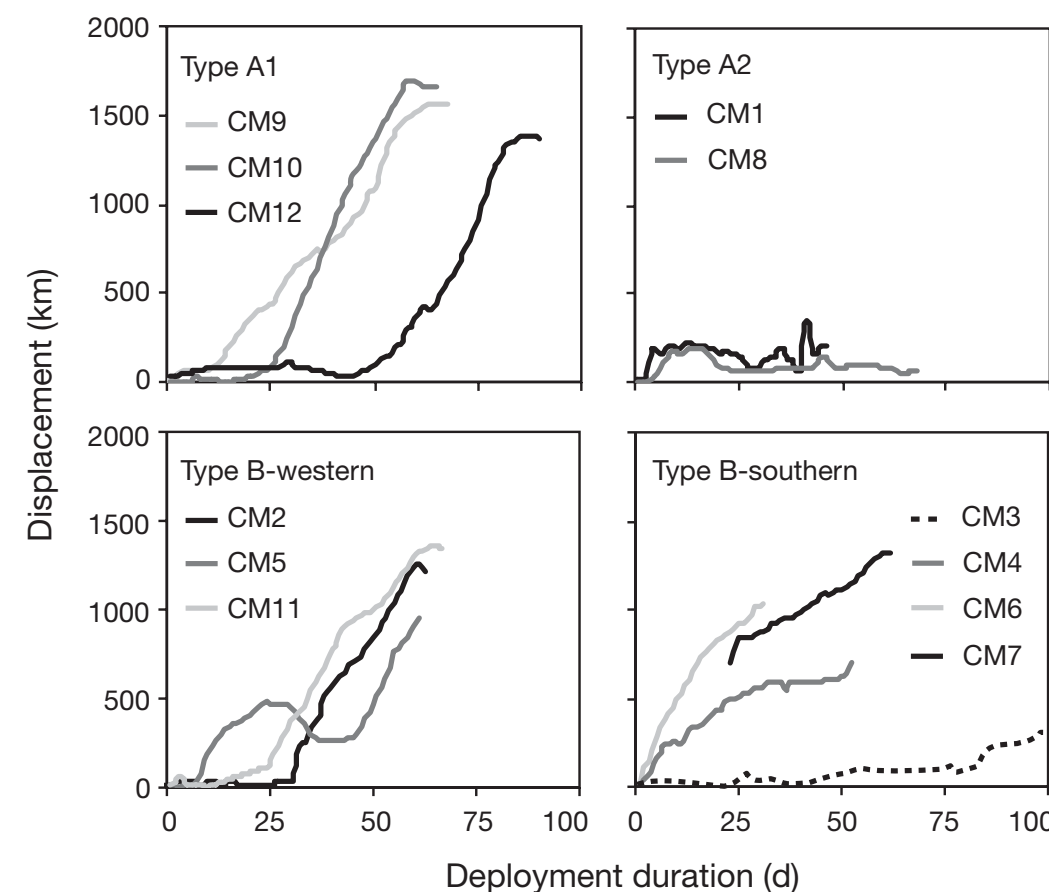

Fig. 2. Chelonia mydas. Displacement plots for green turtles tagged in the Galápagos Islands

Table 1. Satellite data extracted along the track of each turtle. These ocean satellite data products were extracted from the OceanWatch Thematic Realtime Environmental Distributed Data System (THREDDS). MODIS: Moderate Resolution Imaging Spectrometer; GOES: Geostationary Operational Environmental Spacecraft; POES: Polar-orbiting Operational Environmental Spacecraft; AMSR: Advanced Microwave Scanning Radimeter; AVHRR: Advanced Very-High Resolution Radiometer; GFO: Geosat Follow-On; OSCAR: Ocean Surface Currents Analyses; SST: Sea surface temperature; FPI: Frontal Probability Index; SSHa: sea surface height anomaly. When $>1$ sensor is used, the data format is a blended product. In addition, bathymetric data were collected via the General Bathymetric Chart of the Oceans (GEBCO), a global topographic dataset with one minute (1') spatial resolution

\begin{tabular}{|lcccc|}
\hline Parameter & Spacecraft & $\begin{array}{c}\text { Environmental } \\
\text { sensor }\end{array}$ & $\begin{array}{c}\text { Spatial } \\
\text { grid }\end{array}$ & $\begin{array}{c}\text { Composite } \\
\text { duration (d) }\end{array}$ \\
\hline Surface chl a & Aqua & MODIS & $0.05^{\circ} \times 0.05^{\circ}$ & 8 \\
SST & Aqua & MODIS & $0.1^{\circ} \times 0.1^{\circ}$ & 5 \\
& GOES & AMSR-E & $0.1^{\circ} \times 0.1^{\circ}$ & 5 \\
& Imager & $0.1^{\circ} \times 0.1^{\circ}$ & 5 \\
FPI & AVHRR & $0.1^{\circ} \times 0.1^{\circ}$ & 5 \\
SSHa & GOES & Imager & $0.05^{\circ} \times 0.05^{\circ}$ & 14 \\
& Jason-1 & GFO & $0.25^{\circ} \times 0.25^{\circ}$ & $\sim 10$ \\
Ocean currents & & Envisat & $0.25^{\circ} \times 0.25^{\circ}$ & $\sim 10$ \\
Bathymetry & & OSCAR - real time & $1.0^{\circ} \times 1.0^{\circ}$ & 10 \\
& \multicolumn{5}{c}{ GEBCO } & $1^{\prime}$ & - \\
\hline
\end{tabular}


Canny 1986, Cayula \& Cornillon 1995) applied to the daily SST data obtained from the Imager (Table 1). The advantage of this dataset over other SST data sources is the high frequency of the images $\left(48 \mathrm{~d}^{-1}\right)$, which greatly helps to mitigate the obscuring effects of clouds (Castelao et al. 2005). Sea surface current (geostrophic velocity vector) and SSHa data were obtained from the Centre National d'études Spatiales Aviso/Altimetry project (www.aviso.oceanobs.com; Ducet et al. 2000). Satellite-derived chl a pigment concentration data were collected by the Moderate Resolution Imaging Spectrometer (MODIS) and obtained from NASA Goddard Space Flight Center, Ocean Color Project (http:// oceancolor.gsfc.nasa.gov). See Table 1 for a summary of the spacecrafts, environmental sensors, and spatial and temporal resolutions for each of the remotely sensed oceanographic datasets.

Statistical analysis. Argos-derived migration paths were compared to environmental conditions in 3 ways. To determine the water depth along each track line, satellite tracks were overlaid on bathymetric charts; locations in waters $\geq 200 \mathrm{~m}$ deep were considered 'oceanic', whereas those in water $<200 \mathrm{~m}$ were considered neritic. To evaluate turtle movements in relation to surface currents and SSHa, we constructed animations in MapTool of the oceanic movements by turtles tagged in 2005, with each frame representing successive Argos turtle locations overlayed on the spatio-temporally coincident oceanographic data (see Figs. A1 to A7 in Appendix 2, available as Supplementary Material online at: www.int-res.com/articles/ suppl/n004p057_app/). We determined the surface chl a concentration, SSHa, SST, and SST frontal probability at each Argos-derived turtle location and also calculated the mean for each oceanographic variable within a box $\left(0.2^{\circ}\right.$ longitude $\times 0.2^{\circ}$ latitude $\times 5$ to $\left.10 \mathrm{~d}\right)$ centered at the time and position of each satellite transmission and taken to represent the available habitat adjacent to each turtle location. The overall mean values in neritic and oceanic zones for each oceanographic variable were compared using 1-way analysis of variance (ANOVA). We also used ANOVA to compare FPI at Argos locations in the Galápagos neritic, oceanic, and mainland neritic zones with the mean FPI for each respective zone within the entire study area. A non-parametric Kruskal-Wallis test was used to confirm the results of the ANOVA for FPI, as this index occurs in a non-continuous, non-normal data distribution (Hollander \& Wolfe 1999). Ocean satellite data products used for ANOVA were extracted from the OceanWatch Thematic Real-time Environmental Distributed Data System (THREDDS) hosted by the Environmental Research Division of the NOAA Fisheries' Southwest Fisheries Science Center using the program Open-source Project for a Network
Data Access Protocol (OPeNDAP) and analyzed using Matlab (Mathworks).

\section{RESULTS}

Three distinct post-nesting migratory strategies were observed, the patterns of which we classify following the nomenclature of Godley et al. (2008, this Theme Section [TS]). Three turtles conducted oceanic migrations to access neritic foraging areas along the Pacific coast of Central America (hereafter referred to as Type A1 movements), 2 turtles remained in the Galápagos (Type A2 movements), and 7 turtles moved into oceanic waters southwest of the Galápagos (Type B movements) (Table 2, Figs. 2 \& 3). Among turtles conducting Type B movements, there was a tendency for their departures from the Galápagos to be largely west- or south-bound (Type B-western and Type Bsouthern, respectively; Table 2, Figs. 2 \& 3); however, because we are unaware of the final destinations of these turtles, all movements are classified as Type B due to their mutual occurrence in oceanic waters. There was a significant difference in body size among groups (Kruskal-Wallis $H=31.93, \mathrm{p}<0.0001$ ); turtles engaging in Type A1 movements were the largest, while those conducting Type A2 movements were the smallest.

\section{Type A1 movements}

The 3 turtles that migrated to neritic habitats of Central America (Turtles CM9, CM10, and CM12) conducted oceanic migrations that lasted from 31.3 to $53.7 \mathrm{~d}$ (Table 2). Turtle CM9, the largest tracked turtle (96.5 cm CCL), moved northeast along the Cocos Ridge for $\sim 900 \mathrm{~km}$ and past the Nocoya Peninsula (Costa Rica) en route to a neritic site just south of the Gulf of Fonseca (Nicaragua). Turtle CM10 moved along a direct route $(\mathrm{MSI}=0.95)$ past Malpelo Island (Colombia) and into neritic waters of the Gulf of Panama. Turtle CM12 traveled over the Cocos Ridge for $\sim 1000 \mathrm{~km}$, initially heading northwest away from the Galápagos then turning northeast en route to the ridge extending south of Panama, which it followed into the Gulf of Chiriquí (Panama). The mean travel speeds of turtles conducting Type A1 movements were significantly slower in neritic waters of Central America $\left(20.6 \pm 6.0 \mathrm{~km} \mathrm{~d}^{-1}\right)$ compared to oceanic waters $(46.2 \pm$ $\left.5.5 \mathrm{~km} \mathrm{~d}^{-1}\right)(t=9.9, \mathrm{p}=0.03$, Table 2). This decrease was particularly evident for Turtles CM9 and CM10, both of which we believe reached their foraging area destinations based on the shorter daily travel distances at the end of their tracks (Fig. 4). 
Table 2. Post-nesting movement summary. Turtles are grouped according to post-nesting migratory strategy, and movements are summarized as number of days $(\mathrm{d})$, distance $(\mathrm{km})$, and mean speed $\left(\mathrm{km} \mathrm{d}^{-1}\right)$ in each zone. Migration straightness index $(\mathrm{MSI})$ is provided for oceanic movements. CCL: curved carapace length $(\mathrm{cm}) ;(-)$ : no data

\begin{tabular}{|c|c|c|c|c|c|c|c|c|c|c|c|c|c|}
\hline \multirow{2}{*}{ Turtle } & \multirow{2}{*}{$\begin{array}{l}\text { CCL } \\
(\mathrm{cm})\end{array}$} & \multicolumn{3}{|c|}{ — Galápagos neritic —— } & \multicolumn{4}{|c|}{$\longrightarrow$ Oceanic -} & \multirow{2}{*}{\multicolumn{3}{|c|}{$\begin{array}{r}\text { Mainland neritic- } \\
\text { Duration Distance Speed } \\
\left(\mathrm{km} \mathrm{d}^{-1}\right)\end{array}$}} & \multicolumn{2}{|c|}{$\ldots$ Overall $\_$} \\
\hline & & Duration & Distance & $\begin{array}{c}\text { Speed } \\
\left(\mathrm{km} \mathrm{d}^{-1}\right)\end{array}$ & Duration & Distance & Speed & MSI & & & & Duration & Distance \\
\hline \multicolumn{14}{|l|}{ Type A1 } \\
\hline CM9 & 96.5 & 11.1 & 192.3 & 17.3 & 53.7 & 1894.2 & 35.2 & 0.79 & 5.3 & 49.9 & 9.4 & 70.2 & 2136.3 \\
\hline CM10 & 93.0 & 27.2 & 361.7 & 13.3 & 31.0 & 1630.4 & 52.6 & 0.95 & 7.5 & 171.9 & 22.8 & 65.7 & 2164.0 \\
\hline CM12 & 81.0 & 45.1 & 390.0 & 8.6 & 37.3 & 1901.8 & 50.9 & 0.70 & 7.8 & 233.1 & 29.7 & 90.3 & 2524.9 \\
\hline \multicolumn{14}{|l|}{ Type A2 } \\
\hline CM1 & 74.7 & 47.9 & 1396.1 & 29.1 & - & - & - & - & - & - & - & 47.9 & 1396.1 \\
\hline CM8 & 71.6 & 69.0 & 691.9 & 10.3 & - & - & - & - & - & - & - & 69.0 & 691.9 \\
\hline \multicolumn{14}{|c|}{ Type B-western } \\
\hline CM2 & 80.5 & 29.2 & 70 & 2.9 & 30.0 & 1231.7 & 41.0 & 0.95 & - & - & - & 59.1 & 1301.7 \\
\hline CM5 & 87.2 & 7.9 & 143.7 & 18.1 & 54.5 & 1912.1 & 35.1 & 0.50 & - & - & - & 62.5 & 2055.8 \\
\hline CM11 & 83.0 & 9.1 & 205.6 & 22.7 & 58.5 & 1534.8 & 26.2 & 0.87 & - & - & - & 67.6 & 1740.4 \\
\hline \multicolumn{14}{|c|}{ Type B-southern } \\
\hline CM3 & 89.0 & 85.5 & 501.7 & 5.9 & 14.8 & 397.4 & 26.9 & 0.99 & - & - & - & 100.3 & 899.1 \\
\hline CM4 & 86.5 & - & - & - & 58.5 & 1662.5 & 32.4 & 0.60 & - & - & - & 58.5 & 1662.5 \\
\hline CM6 & 82.6 & - & - & - & 33.8 & 1404.5 & 44.7 & 0.75 & - & - & - & 33.8 & 1404.5 \\
\hline $\mathrm{CM}^{\mathrm{a}}$ & 78.0 & - & - & - & 40.1 & 1217.0 & 30.3 & - & - & - & - & 62.1 & 1903.5 \\
\hline
\end{tabular}

\section{Type A2 movements}

The 2 turtles remaining in the Galápagos (Turtles CM1 and CM8) were tracked for 49.1 to $69.0 \mathrm{~d}$ and visited coastal areas of at least 5 different islands, but did not nest again (Fig. 3). Turtle CM1 moved $1396.1 \mathrm{~km}$ after departing the Barahona nesting beach, and traveled at a mean speed of $29.1 \mathrm{~km} \mathrm{~d}^{-1}$ during the tracking period (Table 2). Upon the final Argos transmission, Turtle CM1 was moving along the outer edge of the Galápagos (water depth $>500 \mathrm{~m}$ ) at a travel speed $>45 \mathrm{~km} \mathrm{~d}^{-1}$ and had not yet associated with a neritic foraging habitat. In contrast, Turtle CM8, the smallest turtle tracked $(71.6 \mathrm{~cm} \mathrm{CCL})$, moved to a neritic foraging area along the north coast of Floreana Island that was $75 \mathrm{~km}$ from its nesting site on Isabela Island (Fig. 3). The mean travel speed for Turtle CM8 during its $49 \mathrm{~d}$ at this foraging area was $7.3 \pm 1.2 \mathrm{~km} \mathrm{~d}^{-1}$, compared to a mean travel speed of $17.7 \pm 2.9 \mathrm{~km} \mathrm{~d}^{-1}$ during the $19 \mathrm{~d}$ prior to its arrival at this site.

\section{Type B movements}

The 7 turtles that departed the Galápagos to the southwest did so within 0 to $85.5 \mathrm{~d}$ of tagging and were tracked for 14.8 to $58.5 \mathrm{~d}$ in oceanic waters (Table 2). Turtles CM2 and CM11 moved to the west along a consistent trajectory (MSI $=0.95$ and 0.87 , respectively; Type B-western in Fig. 3). Turtle CM5 also followed this route after first moving in waters south of the Galápagos for the first $49 \mathrm{~d}$ of its deployment. At their final Argos-derived locations, these 3 turtles were at distances of 952 to $1331 \mathrm{~km}$ from the Galápagos and still moving west at travel speeds of 25 to $50 \mathrm{~km} \mathrm{~d}^{-1}$ (Fig. 4). The turtles conducting Type B-southern movements (Turtles CM2, CM4, CM6, and CM7) were last tracked at distances of 395 to $1247 \mathrm{~km}$ from the Galápagos (Type B-southern in Fig. 3). However, the track for Turtle CM3 was too short to provide useful information, while that of Turtle CM7 (the turtle tracked the farthest south) was missing the initial $23 \mathrm{~d}$ of track due to transmitter malfunction, thus preventing a full understanding of this turtle's oceanic movements. Nevertheless, Turtles CM4, CM6, and CM7 were not always moving away from the Galápagos while tracked and each maintained their location in the oceanic zone for at least 2 successive Argos transmissions on one or more occasions. This is particularly evident for Turtle CM4, which moved within a confined oceanographic area centered on $8^{\circ} \mathrm{S}, 92^{\circ} \mathrm{W}$ for $15 \mathrm{~d}$ at the end of its tracking duration (Figs. $2 \& 3$ ).

\section{Oceanographic features}

Integrating the oceanic movements of green turtles with geostrophic surface currents indicates that their movements oriented both with and against prevailing currents. Geostrophic current animations for Type A1 


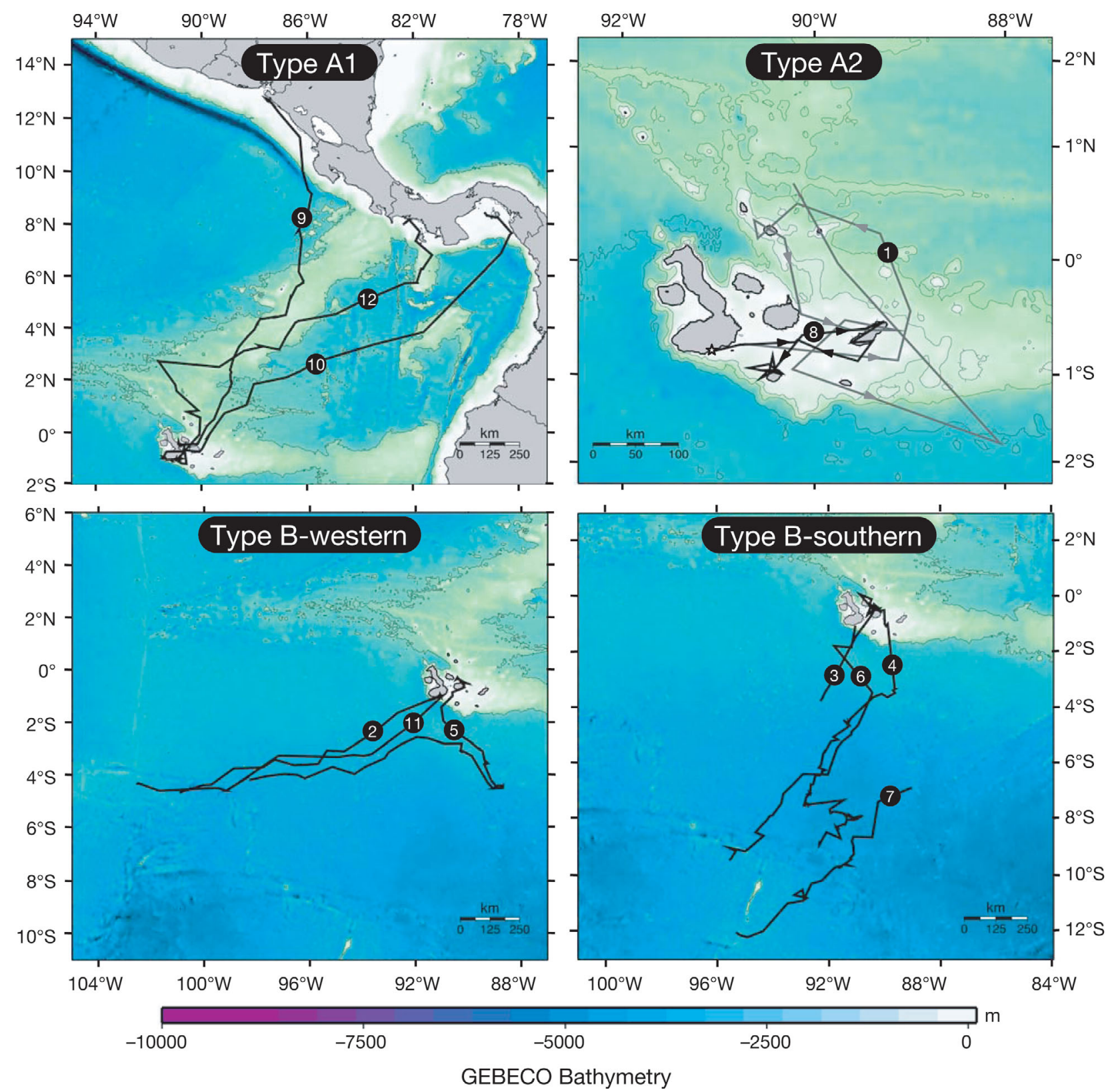

Fig. 3. Chelonia mydas. Satellite-tracked post-nesting movements of green turtles nesting in the Galápagos. Circular labels correspond to each of the 12 tracked turtles (i.e. 1 = CM1). Contour lines denote $2500 \mathrm{~m}$ water depth increments for Type A1 and Type B movements, and $500 \mathrm{~m}$ depth increments for Type A2 movements. Maps constructed with MapTool

movements depict the westward-flowing Northern Equatorial Current (NEC) extending from the Galápagos to $\sim 4^{\circ} \mathrm{N}$, as well as the eastward-flowing Northern Equatorial Countercurrent (NECC) south of the NEC (see Figs. A1 to A3 in Appendix 2). During the initial portions of northbound movements by Turtles CM9 (Fig. A1, Appendix 2) and CM10 (Fig. A2, Appendix 2), both turtles swam against NECC counter-clockwise rotating eddies (CM9 until $8^{\circ} \mathrm{N}$ and $\mathrm{CM} 10$ until $3.8^{\circ} \mathrm{N}$ ) and thereafter moved in concordance with northward flow along the edge of counter-clockwise rotating eddies. The initial movements of Turtle CM12 to the northwest were in concordance with the NEC and at $\sim 3^{\circ} \mathrm{N}$ this turtle turned to the northeast and traveled largely in the same direction as surface currents, moving along the edges of a series of eddies as it progressed toward the coast of Central America (Fig. A3, Appendix 2). The movements by Turtles CM9, CM10 and CM12 to the northwest upon arriving in neritic waters may be reflective of compensatory navigation 

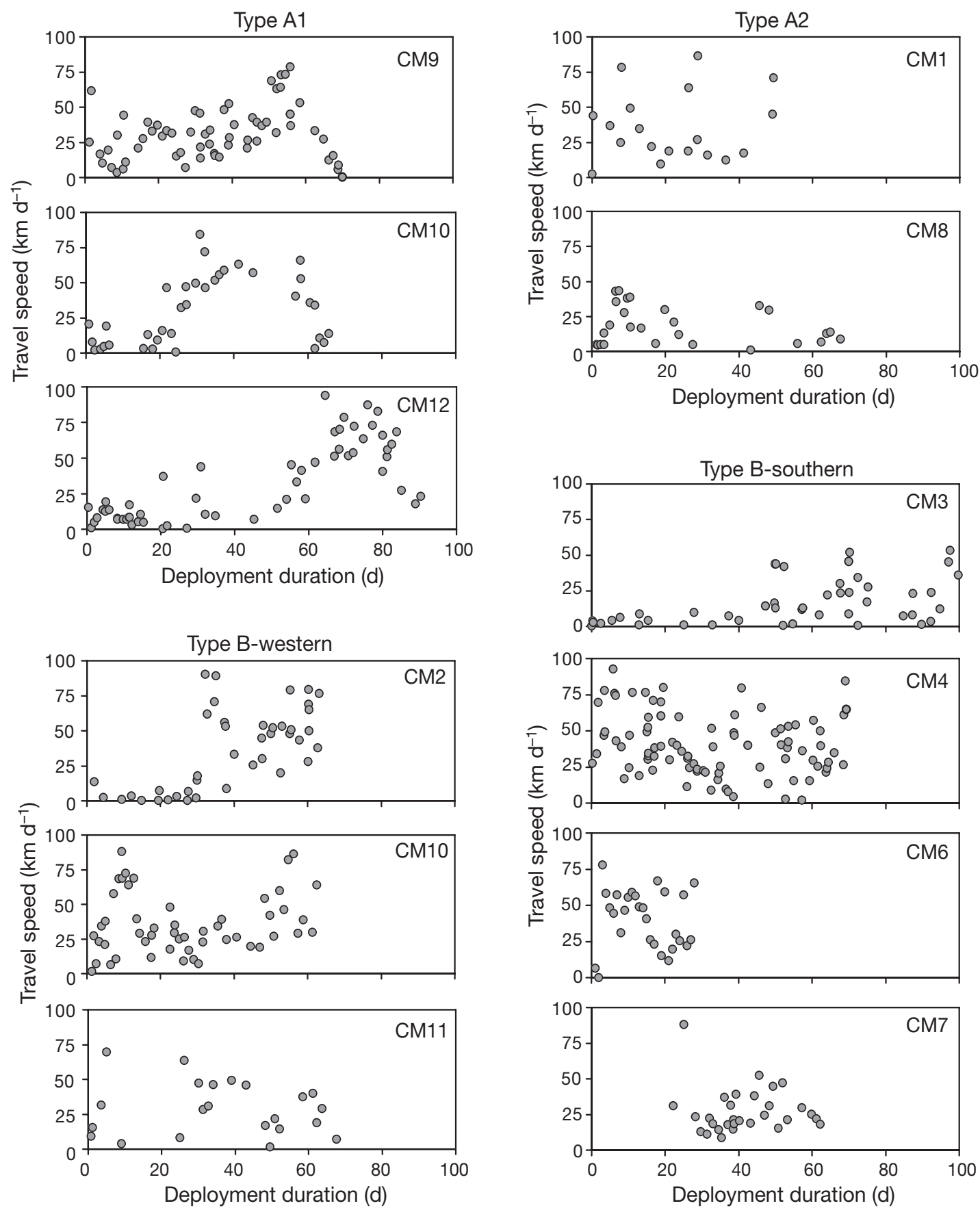

Fig. 4. Chelonia mydas. Swim speeds during satellite-tracked movement of green turtles in the Galápagos Islands

after being pushed to the east during migrations. If so, this suggests that the east-bound NECC and its various filaments were the most influential surface currents north of the Galápagos.

Type B movements were also variably oriented to prevailing surface currents. Turtles CM2 and CM11 (Fig. A4, Appendix 2) swam in concordance with the westward-flowing Southern Equatorial Current
(SEC) for the entirety of their respective tracking durations. Turtle CM5 also moved in parallel to the SEC for the final $13.5 \mathrm{~d}$ of its track, after becoming entrained in east-flowing surface waters and moving southeast for the first $21 \mathrm{~d}$ after leaving the Galápagos (Fig. A5, Appendix 2). At its southernmost location, Turtle CM5 meandered for $11 \mathrm{~d}$ in a very small area and its travel speed slowed to $34.3 \pm 6.0 \mathrm{~km} \mathrm{~d}^{-1}$ com- 
pared to $43.5 \pm 6.1 \mathrm{~km} \mathrm{~d}^{-1}$ during earlier movements and $50.8 \pm 6.2 \mathrm{~km} \mathrm{~d}^{-1}$ during later movements. The remaining Type B movements were more variable in relation to surface currents and there was no apparent major influence by the SEC or other surface currents. Instead, Turtles CM6 and CM7 (Figs. A6 \& A7, respectively, Appendix 2) appeared to move substantial distances against the prevailing currents.

As turtles moved between neritic and oceanic zones, they encountered substantially different oceanographic conditions. A comparison of oceanographic variables in waters adjacent to Argos locations showed that these oceanic and neritic areas had significantly different values for SST, FPI, SSHa ( $p<0.0001)$, but were not different in terms of surface chl a concentration, although we note that this latter relationship was only marginally insignificant ( $\mathrm{p}=0.074$; Table 3 ). Likewise, the Argos-derived turtle locations in neritic and oceanic zones had significantly different values for SST, SSHa, and chl a concentration ( $p<0.05)$, although there was no observed difference for SST front probability ( $p=0.76$; Table 3$)$. The significant difference in mean surface chl a concentration at Argos locations in the neritic $(0.47 \pm 0.22 \mathrm{mg}$ $\left.\mathrm{m}^{-3}\right)$ and oceanic zones $\left(0.18 \pm 0.06 \mathrm{mg} \mathrm{m}^{-3}\right)$ despite the consistency in mean concentration in available waters of the neritic and oceanic zones $(0.35 \pm 0.007$ and $0.34 \pm 0.001 \mathrm{mg} \mathrm{m}^{-3}$, respectively) suggests that chl a concentrations may have influenced turtles differently in these 2 zones (Table 3). In support, the range of chl a concentrations experienced by turtles was much broader in the neritic zone (Fig. 5a,c). With
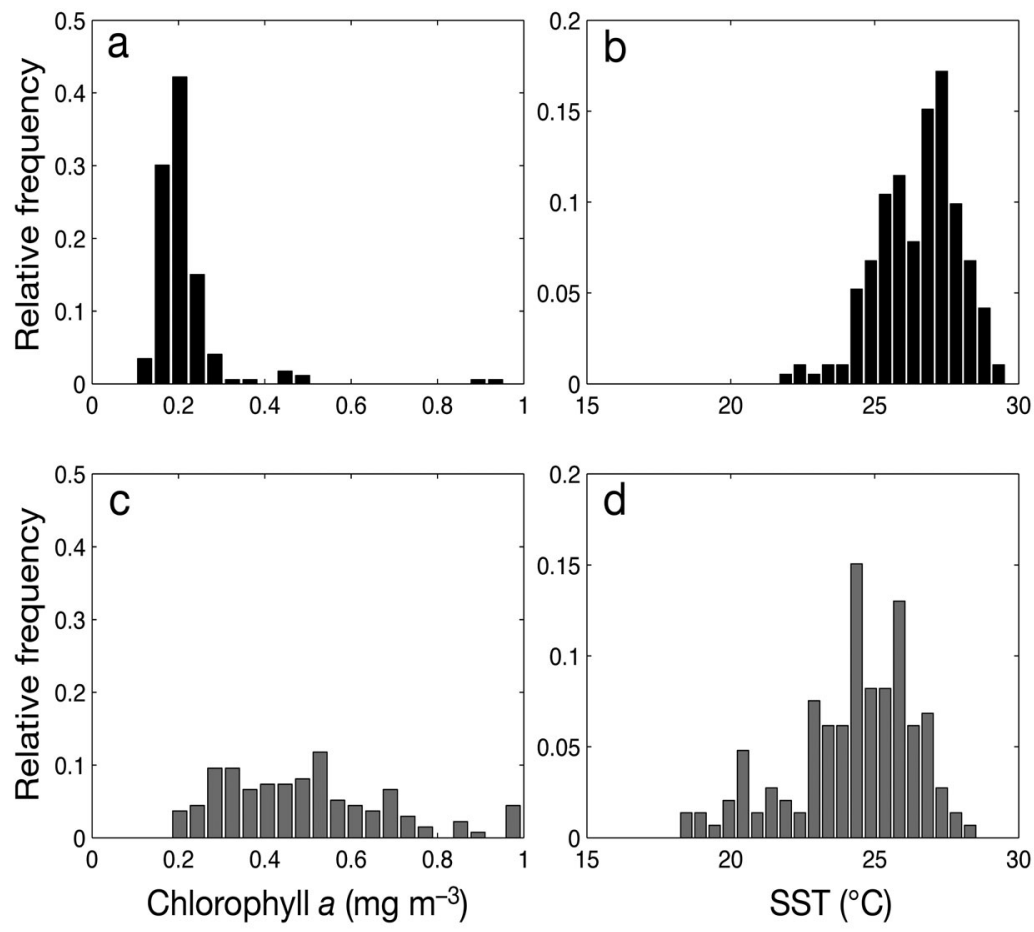

Fig. 5. Comparison of oceanographic variables at each Argos-derived green turtle location. $(\mathrm{a}, \mathrm{c})$ Surface chlorophyll a concentrations and $(\mathrm{b}, \mathrm{d})$ sea surface temperature (SST) in the $(a, b)$ oceanic and $(c, d)$ neritic zones

respect to the thermal environment, green turtles rarely occupied areas with $\mathrm{SST} \leq 24.0^{\circ} \mathrm{C}$, and mean SST along the oceanic portion of the turtles' movements was $>2{ }^{\circ} \mathrm{C}$ warmer than that for their neritic movements (Fig. 5b,d). Selectivity for thermal conditions was also indicated by the propensity of green turtles to access SST frontal zones at rates greater than their availability; i.e. FPI at Argos locations was higher than mean FPI in each respective zone (i.e. Galápagos neritic, oceanic, Central America neritic) within the study area (Table 4).

Table 3. Comparisons of oceanographic conditions in neritic and oceanic zones for all Argos-derived turtle locations as well as the means within a box $\left(0.2^{\circ}\right.$ longitude $\times 0.2^{\circ}$ latitude $\times 5$ to $\left.10 \mathrm{~d}\right)$ centered at the time and position of each satellite transmission and taken to represent the available habitat (i.e. background) adjacent to each turtle location

\begin{tabular}{|c|c|c|c|c|c|c|c|c|c|}
\hline $\begin{array}{l}\text { Oceanographic } \\
\text { variable }\end{array}$ & Data set & $\mathrm{n}$ & $\begin{array}{c}\text { - Neritic } \\
\text { Mean }\end{array}$ & $\mathrm{SE}$ & $\mathrm{n}$ & $\begin{array}{c}\text { Oceanic } \\
\text { Mean }\end{array}$ & $\mathrm{SE}$ & $F$-value & $\begin{array}{c}\text { Significance } \\
\text { (p) }\end{array}$ \\
\hline Surface chl a & $\begin{array}{c}\text { Argos locations } \\
\text { Background }\end{array}$ & $\begin{array}{c}146 \\
5.6 \times 10^{4}\end{array}$ & $\begin{array}{l}0.47 \\
0.35\end{array}$ & $\begin{array}{l}0.014 \\
0.007\end{array}$ & $\begin{array}{c}194 \\
2.7 \times 10^{6}\end{array}$ & $\begin{array}{c}0.18 \\
0.339\end{array}$ & $\begin{array}{l}0.013 \\
0.001\end{array}$ & $\begin{array}{l}237 \\
3.2\end{array}$ & $\begin{array}{c}<0.0001 \\
0.074\end{array}$ \\
\hline SST & $\begin{array}{c}\text { Argos locations } \\
\text { Background }\end{array}$ & $\begin{array}{c}146 \\
1391\end{array}$ & $\begin{array}{l}24.27 \\
24.23\end{array}$ & $\begin{array}{c}0.146 \\
0.07\end{array}$ & $\begin{array}{c}194 \\
6.4 \times 10^{4}\end{array}$ & $\begin{array}{l}26.51 \\
26.31\end{array}$ & $\begin{array}{l}0.128 \\
0.010\end{array}$ & $\begin{array}{l}133 \\
924\end{array}$ & $\begin{array}{l}<0.0001 \\
<0.0001\end{array}$ \\
\hline FPI & $\begin{array}{c}\text { Argos locations } \\
\text { Background }\end{array}$ & $\begin{array}{c}146 \\
2642\end{array}$ & $\begin{array}{c}0.051 \\
0.0453\end{array}$ & $\begin{array}{l}0.0078 \\
0.0019\end{array}$ & $\begin{array}{c}194 \\
1.1 \times 10^{5}\end{array}$ & $\begin{array}{l}0.0475 \\
0.0232\end{array}$ & $\begin{array}{l}0.0067 \\
0.0003\end{array}$ & $\begin{array}{c}0.1 \\
129\end{array}$ & $\begin{array}{c}0.7556 \\
<0.0001\end{array}$ \\
\hline SSHa & $\begin{array}{c}\text { Argos locations } \\
\text { Background }\end{array}$ & $\begin{array}{l}146 \\
784\end{array}$ & $\begin{array}{l}-0.0077 \\
-0.0319\end{array}$ & $\begin{array}{l}0.0038 \\
0.0021\end{array}$ & $\begin{array}{c}194 \\
2.4 \times 10^{4}\end{array}$ & $\begin{array}{l}0.0051 \\
-0.009\end{array}$ & $\begin{array}{l}0.0033 \\
0.0004\end{array}$ & $\begin{array}{l}6.47 \\
116\end{array}$ & $\begin{array}{c}0.01 \\
<0.0001\end{array}$ \\
\hline
\end{tabular}


Table 4. SST Frontal Probability Index (FPI) for Argos locations and background values for neritic and oceanic habitats in the Eastern Tropical Pacific. FPI values were calculated as the fraction of days in a given $14 \mathrm{~d}$ period for which fronts are detected within each $0.05^{\circ} \times 0.05^{\circ}(\sim 5.5 \times 5.5 \mathrm{~km})$ cell in the study area (delineated by $13^{\circ} \mathrm{N}, 13^{\circ} \mathrm{S}, 102^{\circ} \mathrm{W}$, and the coast of Central and South America). All $F$ values denote $95 \%$ significance

\begin{tabular}{|c|c|c|c|c|c|}
\hline FPI location & Data type & $\mathrm{N}$ & Mean \pm SD & $F$ & $\mathrm{p}$ \\
\hline All regions & $\begin{array}{l}\text { Argos locations } \\
\text { Background } \\
\text { Comparison }\end{array}$ & $\begin{array}{c}199 \\
1.12 \times 10^{5}\end{array}$ & $\begin{array}{l}0.0925 \pm 0.007 \\
0.0237 \pm 0.0003\end{array}$ & 96.3 & $<0.0001$ \\
\hline $\begin{array}{l}\text { Galápagos } \\
\text { neritic }\end{array}$ & $\begin{array}{l}\text { Argos locations } \\
\text { Background } \\
\text { Comparison }\end{array}$ & $\begin{array}{c}85 \\
2641\end{array}$ & $\begin{array}{r}0.087 \pm 0.0131 \\
0.0453 \pm 0.0023\end{array}$ & 69.4 & $<0.0001$ \\
\hline Oceanic & $\begin{array}{l}\text { Argos locations } \\
\text { Background } \\
\text { Comparison }\end{array}$ & $\begin{array}{c}101 \\
1.09 \times 10^{5}\end{array}$ & $\begin{array}{l}0.092 \pm 0.01 \\
0.024 \pm 0.003\end{array}$ & 45.3 & $<0.0001$ \\
\hline $\begin{array}{l}\text { Mainland } \\
\text { neritic }\end{array}$ & $\begin{array}{l}\text { Argos locations } \\
\text { Background } \\
\text { Comparison }\end{array}$ & $\begin{array}{c}13 \\
5400\end{array}$ & $\begin{array}{l}0.138 \pm 0.011 \\
0.004 \pm 0.005\end{array}$ & 123 & $<0.0001$ \\
\hline
\end{tabular}

\section{DISCUSSION}

\section{Migratory strategies}

The mosaic of post-nesting migration strategies for Galápagos green turtles, which included north-bound migration to Central America, residency in the Galápagos, and dispersal to oceanic waters southwest of the Galápagos, highlights the substantial flexibility in migratory routes and foraging area destinations for this nesting population. Variability of migratory strategies and foraging habitat affinities within nesting populations is an emerging theme among satellite telemetry studies of sea turtles (see review by Godley et al. 2008). For green turtles, such flexibility has previously been reported for nesting populations in Japan (Hatase et al. 2006) and the Mediterranean (Godley et al. 2003). Among other hard-shelled turtles this trait has been found in olive ridley turtles nesting in northern Australia, which migrate to coastal, continental shelf and continental slope feeding habitats (Whiting et al. 2007). The occupation of diverse foraging habitats after nesting is perhaps most common in loggerheads, as dedicated oceanic and neritic foragers have been documented among nesting populations in Japan (Hatase et al. 2002) and the Cape Verde Islands (Hawkes et al. 2006). Loggerheads nesting in North Carolina, USA, also show foraging area flexibility, with some females accessing temperate northern waters during summer months and others remaining in more southern, warm-water areas for the entirety of their tracking periods (Hawkes et al. 2007). Although the immense spatial scale of such movements may create challenges for conserving these nesting populations, the range of habitat types occupied during non-reproductive periods may contribute to their stability over geologic time scales by buffering against catastrophic oceanographic events (e.g. ENSO, red tide) that affect nesting frequency and abundance.

The observed variation in post-nesting migratory strategy raises intriguing questions about the evolution of migration in sea turtles. Although little is known about how sea turtles choose foraging sites, at least some green turtles are philopatric to specific foraging habitats, returning to the same sites after nesting, year after year (Limpus et al. 1992, Godley et al. 2002, Broderick et al. 2007). If these are within the same ocean regions to which the turtles recruit during hatchling and pelagic juvenile dispersal, then explaining the migration routes and preferred foraging areas would benefit from focused examination of these dispersal mechanisms. Surface currents have been shown to play an important role in hatchling transport (Carr \& Meylan 1980, Bass et al. 2006), and the flow of 4 major current systems (i.e. NEC, NECC, SEC, Peru Current) near the Galápagos may facilitate long-distance dispersal in multiple directions. The numerous current filaments and eddies generated by these convergences may also result in dispersal over only a very short distance from the nesting beach.

Upon recruitment to a foraging area, our results suggest that local conditions can profoundly affect the growth and size-at-maturity of sea turtles. It is interesting to note that the 2 resident turtles (Type A2 movement group) were the smallest turtles tracked during this study. Although we urge caution due to the small sample size, we suggest that their small body size may be due to the high green turtle density in Galápagos foraging habitats and the subsequent poor food availability (Zárate 2007) from which the effects on growth were perhaps enhanced as a result of foraging area philopatry. Adverse density-dependent effects on green turtle growth rate have been reported for green turtles in the Bahamas (Bjorndal et al. 2000) and the fact that juvenile growth rates in the Galápagos are among the slowest in green turtles studied to date $\left(\leq 0.5 \mathrm{~cm} \mathrm{yr}^{-1}\right.$; Green 1993) suggests that density-dependent factors may be ongoing in this region. Phenotypically linked dichotomies in foraging areas, with larger turtles remaining in coastal habitats and smaller turtles occupying oceanic foraging zones, have been reported for loggerheads from the Cape Verde Islands (Hawkes et al. 2006) and Japan (Hatase et al. 2002). Consistent with our reasoning, the 
smaller size of oceanic loggerheads from Japan is believed to be the result of poorer food availability (Hatase et al. 2002). Why smaller turtles would be present in Galápagos neritic versus oceanic waters as reported by Hatase et al. (2002) is unresolved. However, the smaller body size of resident turtles in our study, coupled with the prevalence of Type B movements (oceanic occupancy), suggests that oceanic foraging may be more energetically beneficial than neritic foraging for Galápagos green turtles. To further examine the energetic consequences of remaining in the Galápagos, it would be interesting to compare the reproductive periodicity of residents and migrants, since the rate of nutrient uptake is a major determinant of the interbreeding interval (Bjorndal 1985).

Although prior flipper tagging efforts have demonstrated the movement of green turtles from the Galápagos to the coast of Central America (Green 1984), this is the first study to reveal the specific migratory corridors that are used. The Cocos Ridge and, to a lesser extent, the ridge extending south of Panama appear to be important features associated with green turtle movements to Central America (Type A1 movement group). Although we do not know how these bathymetric features are detected, they may promote oceanographic conditions that are beneficial to migrating turtles. It is interesting that the Cocos Ridge also demarks the primary migratory corridor for leatherback turtles departing nesting beaches in Costa Rica (Morreale et al. 1996). However, it is also possible that these ridges do not directly or indirectly influence green turtle movements and are instead relevant only because of their presence along the most direct routes between the Galápagos and the preferred foraging areas for each turtle. In the absence of surface current influences on open-ocean migration, it is reasonable to expect a nutrient-depleted post-nesting turtle to access its foraging area by the most direct route possible in order to minimize the energetic cost of migration. Indeed, the Pacific coastal areas of Central America are highly productive and host numerous foraging hotspots for green turtles (Cornelius 1982, Amorocho \& Reina 2007).

Whereas green turtles moving to the north were en route to neritic destinations along the coast of Central America, the functions of green turtle movements to the southwest of the Galápagos are less clear. We acknowledge that some of these turtles may have eventually returned to the Galápagos neritic, but because all were still moving away from the Galápagos at the last satellite transmission we believe this is unlikely. Based on geostrophic current plots, it is apparent that the westbound movements of turtles departing the Galápagos in 2003 and 2005 were assisted by the SEC, of which the surface layer from $\sim 5^{\circ} \mathrm{N}$ to $\sim 5^{\circ} \mathrm{S}$ is driven to the west by the prevailing easterly trade winds. The maximum speed of the SEC in this area reaches $25 \mathrm{~cm} \mathrm{~s}^{-1}$ (Kessler 2006) or 53 to $82 \%$ of the overall average speeds of Turtles CM2, CM5, and CM11. The nearly identical west-bound movements of these turtles may thus reflect surface current-facilitated and bearing-mediated movements towards known foraging areas outside the ETP. East Pacific green turtles (based on mitochondrial DNA data; Kuroyanagi et al. 1999) have been found in the western Pacific, and turtles with western Pacific mtDNA haplotypes are regularly sighted in the Galápagos (known locally as yellow turtles; Fritts 1981a, P. H. Dutton unpubl. data), indicating that transPacific movement of green turtles occurs in both directions. If Turtles CM2, CM5, and CM11 continued along the west-southwest trajectory, the nearest neritic habitats they would encounter are in French Polynesia, still $\sim 2500 \mathrm{~km}$ from where the 3 turtles last transmitted. At the rate of travel measured when PTT transmissions ceased ( 26.2 to $41.0 \mathrm{~km} \mathrm{~d}^{-1}$ ), these turtles would require an additional 70 to $95 \mathrm{~d}$ to reach this destination. This $\sim 4000 \mathrm{~km}$ migration would represent one of the longest post-nesting migrations known for green turtles in terms of total distance and duration.

\section{Linking satellite tracks with oceanography}

Green turtles moving in oceanic zones as well as neritic zones in the Galápagos and Central America commonly associated with SST frontal zones. The affinity to these frontal areas is underscored by the fact that the ETP is a region of relatively low frontal activity (Eden \& Timmerman 2004). However, this result should be viewed cautiously since there is a temporal discontinuity between the background FPI calculation (averaged over $14 \mathrm{~d}$ ) and FPI at turtle locations (instantaneous for $1 \mathrm{~d}$ ) in any one $0.05^{\circ} \times 0.05^{\circ}$ cell. Nevertheless, although it is not certain that turtles associated with fronts per se, they at least maintained affinity to areas of more frequent front activity. The strategy used by green turtles to associate with these areas is unclear, although it is unlikely that they were able to detect the fronts at distances of $10 \mathrm{~s}$ to $100 \mathrm{~s}$ of $\mathrm{km}$ and actively navigate to them. Instead, we believe that turtles engaged with frontal zones opportunistically, and remained in such areas only if prey resources were adequate. Most fronts in this region result from current- or wind-induced upwellings, which increase biological productivity (Fiedler 2002a) and may result in greater food abundance in surface waters for sea turtles and other higher order consumers. Thus, by exploiting frontal areas, green turtles may decrease prey search times and increase their feeding effi- 
ciency. To further elucidate green turtle use of frontal zones, it would be helpful to know more about their diving profiles during association with these areas to determine if their dives are shallower than when occupying waters away from thermal fronts.

Although SST frontal areas may constitute important oceanic foraging habitats for green turtles, the absence of east-bound movements toward the coast of South America-an area of substantial frontal activity (Fig. 6) - suggests that SST fronts may only be important if the associated temperatures are within an optimal range. Known as the Peruvian Coastal Upwelling Region (PCUR), the waters east of the Galápagos are among the coldest and most productive within the ETP (Pennington et al. 2006). Considering that this area was dominated by waters $\leq 25^{\circ} \mathrm{C}$ during the 2005 tracking season (Fig. 6), this temperature may represent the thermal threshold below which migrating green turtles actively avoid surface waters. We acknowledge that the lack of movements into the PCUR may be an artifact of small sample size or perhaps because accessing this area would require swimming against the prevailing SEC and Peru Current. However, we doubt that surface currents were a major factor in this lack of eastward movements since green turtles were found to

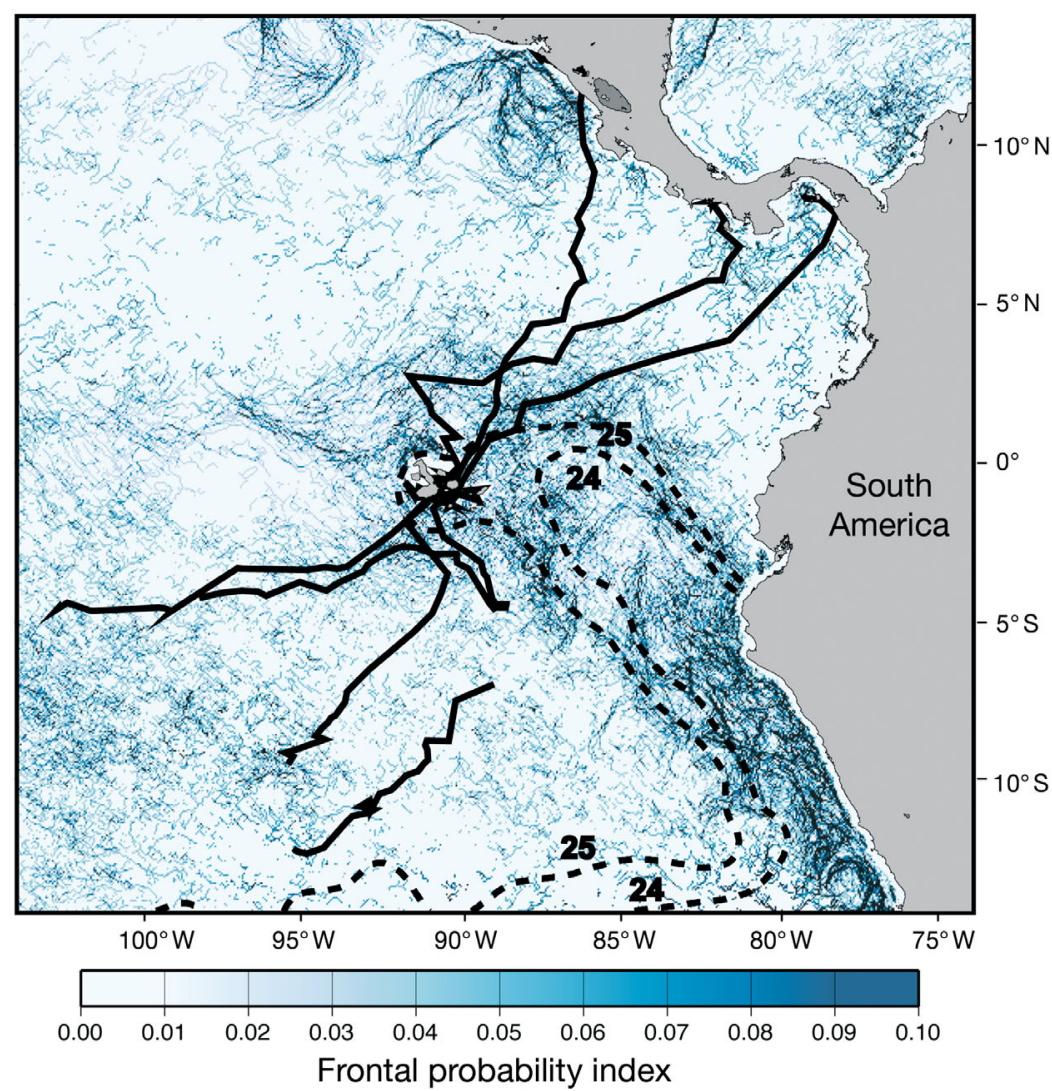

Fig. 6. Chelonia mydas. Green turtle post-nesting paths (continuous black lines) in 2005 in relation to frontal zones and SST contour locations (dashed lines) swim countercurrent in other areas during this study. With respect to SST, Godley et al. (2002) reported a marked shift in diving behavior by migrating green turtles in the Mediterranean when mean sea temperatures dropped below $25^{\circ} \mathrm{C}$, further supporting the likelihood that green turtles from the Galápagos avoided the PCUR due to its low surface temperatures. Interestingly, turtles in the Galápagos neritic appear willing to experience colder water, perhaps the result of a greater thermal tolerance during internesting behavior, but also possibly due to smaller-scale movements by turtles in these areas and the correspondingly lesser opportunity to choose specific water temperatures. It would be interesting to conduct telemetry studies of Galápagos green turtles during periods of elevated SST (i.e. ENSO) to determine if turtles are more likely to access waters east of the Galápagos during these periods. If so, these warming episodes may provide a mechanism for green turtles to access foraging habitats along the coast of South America.

In addition to thermal conditions, sea surface chl $a$ concentration appears to be an oceanographic variable that influenced green turtle movements. Oceanic migrations occurred in waters with a mean sea surface chl a concentration of $0.18 \mathrm{mg} \mathrm{m}^{-3}$ and Argos locations were tightly grouped around the $0.2 \mathrm{mg}$ $\mathrm{m}^{-3}$ surface chl a contour. This is consistent with satellite-tracked movements of loggerhead turtles foraging along the North Pacific transition zone chlorophyll front (TZCF) (Polovina et al. 2001). The $0.2 \mathrm{mg} \mathrm{m}^{-3}$ surface chl a contour is considered a proxy for identifying the convergence zone between the stratified low surface chl a $\left(<0.15 \mathrm{mg} \mathrm{m}^{-3}\right)$ waters and the high surface chl $a$ $\left(>0.3 \mathrm{mg} \mathrm{m}^{-3}\right)$ vertically mixed waters (Polovina et al. 2000, 2001). This convergence zone is biologically important since the intersection of these 2 chlorophyll masses often results in the increased abundance of zooplankton and other buoyant organisms (Olson et al. 1994, Polovina et al. 2000, 2001, Graham et al. 2001) that constitute important food resources for marine predators. However, it should also be noted that the attenuation of light underwater increases exponentially with surface chl $a$ (Smith \& Baker 1978), the result being that waters with a surface chl a concentration of $0.2 \mathrm{mg} \mathrm{m}^{-3}$ are relatively clear, and likely beneficial to visual predators such as sea turtles. Thus, the affinity of green turtles to waters with a $0.2 \mathrm{mg}$ 
$\mathrm{m}^{-3}$ surface chl a concentration may simply indicate their preference for clear water.

The localized movements of green turtles in areas south of the Galápagos, coupled with their association with preyconducive surface chlorophyll levels and SST fronts, underscores the likelihood that at least some green turtles foraged in oceanic waters during tracking efforts. Oceanic foraging by green turtles has been demonstrated via stable

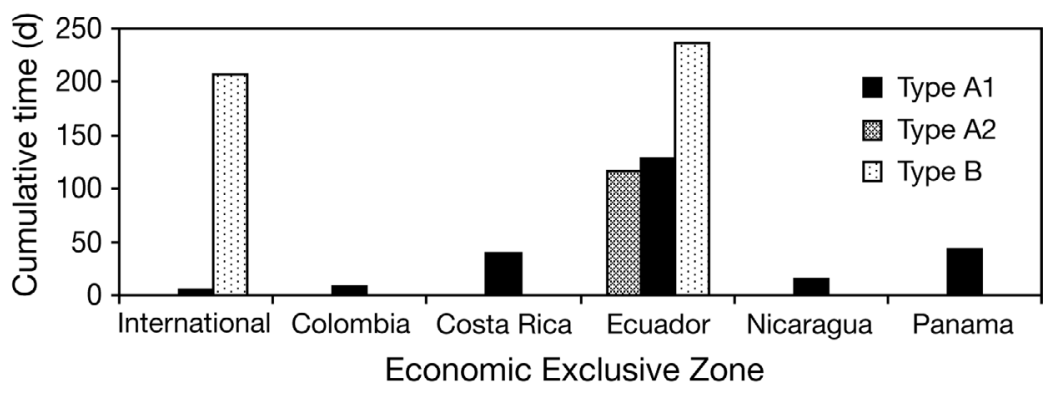
isotope analyses by Hatase et al. (2006).

Fig. 7. Jurisdictional waters occupied by green turtles during post-nesting movements tracked with satellite telemetry

Parker \& Balazs (in press) analyzed stomachs of green turtles bycaught in oceanic zones of the central Pacific and found a variety of oceanic prey species such as sea jellies Pyrosoma sp., commonly found at the surface, gooseneck barnacles Lepas sp., which adhere to floating objects, and Janthina sp., a gastropod that occurs at the sea surface with the assistance of a gas-filled float, as well as > 20 additional oceanic species. Green turtles captured in pelagic zones off mainland Ecuador and Peru have had stomachs filled with fish eggs (Fritts 1981b, Hays-Brown \& Brown 1982). However, despite this evidence of oceanic foraging by green turtles, the strategies used to access oceanic prey resources remain poorly understood. To study this behavior we encourage additional satellite telemetry efforts that employ GPS and dive-profiling technology to reveal the exact locations of green turtles in relation to oceanographic features as well as depict the actual diving activity and surfacing intervals in these areas.

\section{Conservation implications}

Green turtles nesting within the Galápagos are protected by the Galápagos Biological Reserve of Marine Resources; however, after nesting, the majority of turtles swim to distant foraging areas that have less highly regulated and largely unmanaged exploitation of sea turtles (e.g. Chacón 2002). Turtles tracked during the present study traveled for substantial periods in international waters and entered jurisdictional waters of 5 Latin American nations (Fig. 7), all of which have been shown to have ongoing human impacts on sea turtles in neritic foraging areas (Cornelius 1982, Chacón 2002, Amorocho et al. 2005). Although not visited by green turtles during this study, coastal regions in Peru and mainland Ecuador also have high levels of directed take (de Paz et al. 2002, M. Helvey pers. comm.), further underscoring the widespread nature of green turtle hunting in the ETP. With regard to bycapture in fisheries gear, Arauz et al. (2000) describe a catch per unit effort of 0.85 green turtles per 100 hooks in Costa
Rican longline fisheries operating east of the Galápagos. Green turtles are also the second most common sea turtle species bycaught in Peruvian artisanal shark longline fisheries (Kelez-Sara et al. 2006) and Colombian shrimp trawl fisheries (Amorocho et al. 2005), and have been killed as the result of bycatch in artisanal fisheries in Panama (P. Zarate unpubl. data) and Chile (M. Donoso pers. comm.). Together, these threats may have substantial negative effects on the Galápagos nesting population. A decline in the annual number of nesting females from 2000 to 2006 at the 4 primary beaches (Zárate 2007) suggests that the consequences of these effects are apparent at the nesting beaches.

Global conservation efforts have largely focused on nesting beaches, representing only a fraction of marine turtle life history, but it is now clear that safeguarding the migratory corridors and neritic foraging areas is essential. Fortunately, there are several sea turtle conservation initiatives ongoing in the ETP that may help protect sea turtles. Those turtles traveling north from the Galápagos to areas near Cocos Island (Costa Rica), Coiba Island (Panama), and Gorgona and Malpelo Islands (Colombia) are legally protected by the Marine Conservation and Sustainable Development Corridor, an initiative of the governments of Costa Rica, Panama, Colombia, and Ecuador which promotes sustainable management of marine resources within this part of the ETP. The Eastern Tropical Pacific Seascape Project is a complementary effort by non-governmental organizations which aims to protect a variety of marine vertebrate species within this same area (UNESCO 2006). Additional international instruments such as the InterAmerican Tropical Tuna Commission (IATTC) and Inter-American Convention for the Protection and Conservation of Sea Turtles (IAC) are also designed to lessen the effects on sea turtles from fisheries and other human impacts. While clearly no single law or treaty can be $100 \%$ effective at minimizing anthropogenic impacts on sea turtles, these international agreements and laws provide a framework within which conservation advances can be made. However, there is also a need for a broad-based, cohesive sea 
turtle conservation plan that targets all sea turtle species occurring in the ETP. The Permanent Commission of the South Pacific, under the Lima Convention, has developed an Action Plan for Sea Turtles in the Southeast Pacific (CPPS 2006), and is perhaps the most relevant of the international instruments in this region since all 5 nations from Panama to Chile are signatories. However, the successful implementation of this plan will require additional data on sea turtle biology and fisheries impacts as well as explicit discussion of the viable solutions to the ongoing problems. Clearly, such an effort would benefit from the participation and input of a diverse group including sea turtle biologists, wildlife managers, economists, fishers, and policy experts to address the growing challenges.

Acknowledgements. We thank C. Chasiluisa, M. Chica, M. Farias, C. Hasbun, R. LeRoux, and N. de Paz for their assistance with this project. Logistic and financial support was provided by the Charles Darwin Research Station and NOAA-National Marine Fisheries Service. We also thank R. Arauz, G. Balazs, M. Chaloupka, B. Godley, R. Kennett, and Y. Matsuzawa for providing information for this paper. B. Godley, B. Wallace and 4 anonymous reviewers provided valuable comments that helped improve earlier versions of this manuscript. Research permits were provided by the Galápagos Biological Reserve of Marine Resources.

Dedication. This article is dedicated to our friend and colleague Boyd Nathaniel Lyon (1969-2006). Boyd was taken from us much too early, while doing one of the things he loved most: researching the in-water ecology of green turtles. He was among the best and brightest rising stars and was able to touch the lives of many fellow researchers during his years as part of our research community. His passion, attention to detail, and robust spirit is an inspiration to all.

\section{LITERATURE CITED}

Alvarado J, Figueroa A (1992) Recapturas post-anidatorias de hembras de tortuga marina negra (Chelonia agassizi) marcadas en Michoacan, Mexico. Biotropica 24:560-566

Amorocho DF, Reina RD (2007) Feeding ecology of the East Pacific green sea turtle Chelonia mydas agassizii at Gorgona National Park, Colombia. Endang Species Res 3:43-51

Amorocho D, Barreto L, Zapata L (2005) Disminución del impacto por captura incidental en tortugas marinas con el uso de anzuelos curvos.Informe Técnico WWF-Colombia, Cali

Arauz R, Rodríguez O, Vargas R, Segura A (2000) Incidental capture of sea turtles by Costa Rica's longline fleet. In: Kalb H, Wibbels $\mathrm{T}$ (compilers) Proceedings of the 19th Annual Symposium on Sea Turtle Biology and Conservation. NOAA Tech Memo NMFS-SEFSC-443, National Marine Fisheries Service, Miami, FL, p 21-26

Balazs GH, Miya RK, Beaver SC (1996) Procedures to attach a satellite transmitter to the carapace of an adult green sea turtle, Chelonia mydas. In: Keinath JA, Barnard DE, Musick JA, Bell BA (compilers) Proceedings of the 15th Annual Symposium on Sea Turtle Biology and Conservation, NOAA Tech Memo, NMFS-SEFSC-387, National Marine Fisheries Service, Miami, FL, p 21-26

Bass AL, Epperly SP, Braun-McNeill J (2006) Green turtle (Chelonia mydas) foraging and nesting aggregations in the Caribbean and Atlantic: impact of currents and behavior on dispersal. J Hered 97:346-354

Bjorndal KA (1985) Nutritional ecology of sea turtles. Copeia 1985:736-751

Bjorndal KA, Bolten AB, Chaloupka MY (2000) Green turtle somatic growth model: evidence for density dependence. Ecol Appl 10:269-282

Blumenthal JM, Solomon JL, Bell CD, Austin TJ and others (2006) Satellite tracking highlights the need for international cooperation in marine turtle management. Endang Species Res 2:51-61

Breaker LC, Mavor TP, Broenkow WW (2005) Mapping and monitoring large-scale ocean fronts off the California Coast using imagery from the GOES-10 geostationary satellite. Publ T-056, California Sea Grant College Program, University of California, San Diego, La Jolla, CA

Broderick AC, Coyne MS, Fuller WJ, Glen F, Godley BJ (2007) Fidelity and over-wintering of sea turtles. Proc R Soc Lond B Biol Sci 274:1533-1538

Canny J (1986) A computational approach to edge-detection. IEEE Trans Pattern Anal Mach Intell 8:679-698

> Carr A, Meylan AB (1980) Evidence of passive migration of green turtle hatchlings in Sargassum. Copeia 1980: 366-368

Carr A, Carr MH, Meylan AB (1978) The ecology and migrations of sea turtles, 7 . The west Caribbean green turtle colony. Bull Am Mus Nat Hist 162:1-46

> Castelao RM, Barth JA, Mavor TP (2005) Flow-topography interactions in the northern California Current System observed from geostationary satellite data. Geophys Res Lett 32:L24612

Cayula JF, Cornillon P (1995) Multi-image edge detection for SST images. J Atmos Ocean Technol 12:821-829

Chacón D (2002) Assessment about the trade of sea turtles and their products in the Central American isthmus. Red Regional para la Conservación de last Tortugas Marinas en Centroamérica. San José, Costa Rica

Chavez FP, Strutton PG, Friederich GE, Feely RA, Feldman GC, Foley DG, McPhaden MJ (1999) Biological and chemical response of the equatorial Pacific Ocean to the 1997-98 El Niño. Science 286:2126-2131

$>$ Cheng IJ (2000) Post nesting migrations of green turtles (Chelonian mydas) at Wan-An Island, Penghu Archipelago, Taiwan. Mar Biol 137:747-754

Cornelius SE (1982) Status of sea turtles along the Pacific coast of Middle America. In: Bjorndal KA (ed) Biology and conservation of sea turtles. Smithsonian Institute Press, Washington, DC, p 211-219

Coyne MC, Godley BJ (2005) Satellite Tracking and Analysis Tool (STAT): an integrated system for archiving, analyzing and mapping animal tracking data. Mar Ecol Prog Ser 301: $1-7$

CPPS (Comisión Permanente del Pacífico Sur) (2006) Plan de Acción para la Protección del Medio Marino y Áreas Costeras del Pacífico Sudeste. Comisión Permanente del Pacífico Sur, Guayaquil, Ecuador

> Craig P, Parker D, Brainard R, Rice M, Balazs G (2004) Migrations of green turtles in the central South Pacific. Biol Conserv 116:433-438

de Paz N, Reyes J, Echegaray M (2002) Datos sobre captura, comercio y biología de tortugas marinas en el área de Pisco-Paracas. In: Mendo J, Wolf M (eds) Jornada Científica Reserva Nacional de Paracas. Universidad Nacional Agraria La Molina, Lima, p 125-129

> Dethmers KEM, Broderick D, Moritz C, FitzSimmons NN and others (2006) The genetic structure of Australasian green turtles (Chelonia mydas): exploring the geographical scale of genetic exchange. Mol Ecol 15:3931-3946 
Doniol-Valcroze T, Berteaux D, Larouche P, Sears R (2007) Influence of thermal fronts on habitat selection by four rorqual whale species in the Gulf of St. Lawrence. Mar Ecol Prog Ser 335:207-216

Ducet N, LeTraon PY, Reverdin G (2000) Global high resolution mapping of ocean circulation from Topex/Poseidon and ERS-1 and -2. J Geophys Res 105:19477-19498

Eden C, Timmerman A (2004) The influence of the Galápagos Islands on tropical temperatures, currents, and the generation of tropical instability waves. Geophys Res Lett 31: L15308

Etnoyer P, Canny D, Mate BR, Morgan LE, Ortega-Ortiz JG, Nichols WJ (2006) Sea-surface temperature gradients across blue whale and sea turtle foraging trajectories off the Baja California Peninsula, Mexico. Deep-Sea Res II 53:340-358

Fiedler PC (2002a) Environmental change in the eastern tropical Pacific Ocean: review of ENSO and decadal variability. Mar Ecol Prog Ser 244:265-283

Fiedler PC (2002b) The annual cycle and biological effects of the Costa Rica Dome. Deep-Sea Res I 49:321-338

> Fiedler PC, Bernard HJ (1987) Tuna aggregation and feeding near fronts observed in satellite imagery. Cont Shelf Res 7: $871-881$

Fritts TH (1981a) Marine turtles of the Galápagos Islands and adjacent areas of the eastern Pacific on the basis of observations made by J. R. Slevin 1905-1906. J Herpetol 15:293-301

Fritts TH (1981b) Pelagic feeding habits of turtles in the eastern Pacific. Mar Turt Newsl 17:4-5

Godley BJ, Richardson S, Broderick AC, Coyne MS, Glen F, Hays GC (2002) Long-term satellite telemetry of the movements and habitat utilization by green turtles in the Mediterranean. Ecography 25:352-362

Godley BJ, Broderick AC, Glen F, Hays GC (2003) Post-nesting movements and submergence patterns of loggerhead marine turtles in the Mediterranean assessed by satellite tracking. J Exp Mar Biol Ecol 287:119-134

Godley BJ, Blumenthal JM, Broderick AC, Coyne MS, Godfrey MH, Hawkes LA, Witt MJ (2008) Satellite tracking of sea turtles: Where have we been and where do we go next? Endang Species Res 4:3-22

Graham WM, Pagès F, Hamner WM (2001) A physical context for gelatinous zooplankton aggregations: a review. Hydrobiologia 451:199-212

> Green DJ (1984) Long-distance movements of Galápagos green turtles. J Herpetol 18:121-130

$>$ Green DJ (1993) Growth rates of wild immature green turtles in the Galápagos Islands, Ecuador. J Herpetol 27:338-341

Green D, Ortiz-Crespo F (1982) Status of sea turtle populations in the central eastern Pacific. In: Bjorndal KA (ed), Biology and conservation of sea turtles. Smithsonian Institution Press, Washington, DC, p 221-234

Hatase H, Takai N, Matsuzawa Y, Sakamoto W, Omuta K, Goto K, Arai K, Fujiwara T (2002) Size-related differences in feeding habitat use of adult female loggerhead turtles Caretta caretta around Japan determined by stable isotope analyses and satellite telemetry. Mar Ecol Prog Ser 233:273-281

Hatase H, Sato K, Yamaguchi M, Takahashi K, Tsukamoto K (2006) Individual variation in feeding habitat use by adult green sea turtles (Chelonia mydas): are they obligately neritic herbivores? Oecologia 149:52-64

- Hawkes LA, Broderick AC, Coyne MS, Godfrey MS and others (2006) Phenotypically linked dichotomy in sea turtle foraging requires multiple conservation approaches. Curr Biol 16:990-995
Hawkes LA, Broderick AC, Coyne MS, Godfrey MH, Godley BJ (2007) Only some like it hot - quantifying the environmental niche of the loggerhead sea turtle. Divers Distrib 13: $447-457$

Hays GC, Dray M, Quaife T, Smyth TJ and others (2001) Movements of migrating green turtles in relation to AVHRR derived sea surface temperature. Int J Remote Sens 22: 1403-1411

Hays GC, Luschi P, Papi F, del Seppia C, Marsh R (2002) Bi-phasal long-distance migration in green turtles. Anim Behav 64:895-898

Hays-Brown C, Brown WM (1982) Status of sea turtles in the southeastern Pacific: emphasis on Peru. In: Bjorndal KA (ed) Biology and conservation of sea turtles. Smithsonian Institution Press, Washington, DC, p 235-240

Heylings P, Bensted-Smith R, Altamirano M (2002) Zonificación e historia de la Reserva Marina de Galápagos. In: Danulat E, Edgar GJ (eds) Reserva Marina de Galápagos, Línea Base de la Biodiversidad. Fundación Charles Darwin/Servicio Parque Nacional Galápagos, Santa Cruz, Galápagos, p 10-37

Hollander M, Wolfe DA (1999) Nonparametric statistical methods, 2nd edn. Wiley \& Sons, New York

IOC IHO, BODC (2003) Centenary edition of the GEBCO digital atlas. British Oceanographic Data Centre, Liverpool

Kelez-Sara S, Manrique-Bravo C, Velez-Zuazo X (2006) Shark longline fishey and sea turtles in Peruvian waters. In: Frick M, Panagopoulou A, Rees AF, Williams K (compilers). Book of Abstracts; 26th Annual Symposium on Sea Turtle Biology and Conservation. International Sea Turtle Society, Athens, p 262-263

Kennett R, Munungurritj N, Yunupingu D (2004) Migration patterns of marine turtles in the Gulf of Carpinteria, northern Australia: implications for aboriginal management. Wildl Res 31:241-248

Kessler WS (2006) The circulation of the eastern tropical Pacific: a review. Prog Oceanogr 69:181-217

Kuroyanagi K, Kamezaki N, Sugiyama S (1999) First confirmed black sea turtle (C. m. agassizii) in Japanese waters. Umigame Newsl Jpn 39:13-14

Limpus CJ, Miller J, Parmenter CJ, Reimer D, McLachlan N, Webb R (1992) Migration of green (Chelonia mydas) and loggerhead (Caretta caretta) turtles to and from eastern Australian rookeries. Wildl Res 19:347-358

Luschi P, Hays GC, del Seppia C, Marsh R, Papi F (1998) The navigational feats of green sea turtles migrating from Ascension Island investigated by satellite telemetry. Proc R Soc Lond B Biol Sci 265:2279-2284

Luschi P, Hays GC, Papi F (2003) A review of long-distance movements by marine turtles, and the possible role of ocean currents. Oikos 103:293-302

Morreale SJ, Standora EA, Spotila JR, Paladino FV (1996) Migration corridor for sea turtles. Nature 384:319-320

Musick JA, Limpus CJ (1997) Habitat utilization and migration in juvenile sea turtles. In: Lutz PL, Musick JA (eds) The biology of sea turtles. CRC Press, Boca Raton, FL, p 137-163

Olson DB, Hitchcock GL, Mariano AJ, Ashjian CJ, Peng G, Nero RW, Podesta GP (1994) Life on the edge: marine life and fronts. Oceanography 7:52-59

Palacios DM (2002) Factors influencing the island-mass effect of the Galápagos Islands. Geophys Res Lett 29:2134

Palacios DM, Bograd SJ, Foley DG, Schwing FB (2006) Oceanographic characteristics of biological hot spots in the North Pacific: a remote sensing perspective. Deep-Sea Res II 53:250-269

Parker DM, Balazs GH (in press) Diet of the oceanic green turtle, Chelonia mydas, in the North Pacific. In: Proceedings of the 25th International Symposium on Sea Turtle Biology 
and Conservation, National Marine Fisheries Service, Miami, FL

Pelletier D, Roos D, Ciccione S (2003) Oceanic survival and movements of wild and captive reared immature green turtles (Chelonia mydas) in the Indian Ocean. Aquat Living Resour 16:35-41

Pennington JT, Mahoney KL, Kuwahara VS, Kolber DD, Calienes R, Chavez FP (2006) Primary production in the eastern tropical Pacific: a review. Prog Oceanogr 69: 285-317

Plotkin P (2003) Adult migrations and habitat use. In: Lutz PL, Musick JA, Wyneken J (eds) The biology of sea turtles, Vol 2. CRC Press, Boca Raton, FL, p 225-242

Plotkin PT, Byles RA, Rostal DC, Owens DW (1995) Independent versus socially facilitated oceanic migrations of the olive ridley, Lepidochelys olivacea. Mar Biol 122:137-143

Podesta GP, Brower JA, Hoey JJ (1993) Exploring the association between swordfish catch rates and thermal fronts on United States longline grounds in the Western NorthAtlantic. Cont Shelf Res 13:253-277

Polovina JR, Kobayashi DR, Parker DM, Seki JP, Balazs GH (2000) Turtles on the edge: movements of loggerhead turtles (Caretta caretta) along oceanic fronts, spanning longline fishing grounds in the central North Pacific, 1997-1998. Fish Oceanogr 9:71-82

Polovina JJ, Howell EE, Kobayashi DR, Seki MP (2001) The transition zone chlorophyll front, a dynamic global feature defining migration and forage habitat for marine resources. Prog Oceanogr 49:469-483

Polovina J, Uchida I, Balazs G, Howell EA, Parker D, Dutton P (2006) The Kuroshio Extension Bifurcation Region: a pelagic hotspot for juvenile loggerhead sea turtles. Deep-Sea Res II 53:326-339

Saba VS, Santidrián-Tomillo P, Reina RD, Spotila JR, Musick JA, Evans DA, Paladino FV (2007) The effect of the El
Niño Southern Oscillation on the reproductive frequency of eastern Pacific leatherback turtles. J Appl Ecol 44: 395-404

Smith RC, Baker KS (1978) The bio-optical state of ocean waters and remote sensing. Limnol Oceanogr 23: $247-259$

Strub PT, Mesias J, James C (1995) Satellite observations of the Peru-Chile countercurrent. Geophys Res Lett 22:211-214

Strub PT, Mesias JM, Montecino V, Rutllant J, Salinas S (1998) Coastal ocean circulation off Western South America. In: Robinson AR, Brink KH (eds) The sea (coastal oceans), Vol 11. Wiley, New York, p 273-313

Troëng S, Evans DR, Harrison E, Lagueux CJ (2005) Migration of green turtles Chelonia mydas from Tortuguero, Costa Rica. Mar Biol 148:435-447

UNESCO (2006) Eastern Tropical Pacific Seascape Project. Available at: http://whc.unesco.org/en/activities/14/ (Downloaded on 30 October 2006)

Wessel P, Smith WHF (1991) Free software helps map and display data. Eos 72:445-446

Whiting SD, Long JL, Coyne M (2007) Migration routes and foraging behaviour of olive ridley turtles Lepidochelys olivacea in northern Australia. Endang Species Res 3:1-9

Worm B, Sandow M, Oschlies A, Lotze HK, Myers RA (2005) Global patterns of predator diversity in the open oceans. Science 309:1365-1369

Zárate P (2007) Assessment of the foraging areas of marine turtles in the Galápagos Islands: 2000-2006. Final report to NOAA-National Marine Fisheries Service. Charles Darwin Foundation, Puerto Ayora, Galápagos

Zárate P, Dutton P (2002) Tortuga verde. In: Danulat E, Edgar GJ (eds) Reserva Marina de Galápagos. Línea base de la biodiversidad. Fundación Charles Darwin/Servicio Parque Nacional Galápagos, Santa Cruz, Galápagos, p 305-323

Appendix 1. Satellite transmitter performance for 12 deployments on green turtles Chelonia mydas. Data for each individual includes date of deployment, start and end dates of satellite transmissions, days at large, and number of satellite uplinks summarized by location class (LC). BA: Barahona; LS: Las Salinas; QP: Quinta Playa; see Fig. 1 for tagging site locations

\begin{tabular}{|c|c|c|c|c|c|c|c|c|c|c|c|c|c|}
\hline Turtle & $\begin{array}{l}\text { Tagging } \\
\text { site }\end{array}$ & $\begin{array}{l}\text { Date of } \\
\text { release }\end{array}$ & $\begin{array}{c}\text { Date of } \\
\text { first location }\end{array}$ & $\begin{array}{c}\text { Date of } \\
\text { final location }\end{array}$ & $\begin{array}{c}\text { Track } \\
\text { duration (d) }\end{array}$ & 3 & 2 & 1 & $\begin{array}{c}\mathrm{LC} \\
0\end{array}$ & A & B & $\mathrm{Z}$ & $\begin{array}{c}\text { Total } \\
\text { uplinks }\end{array}$ \\
\hline CM-1 & BA & 25 Feb 03 & 28 Feb 03 & 17 Apr 03 & 51 & 0 & 1 & 4 & 6 & 9 & 16 & 1 & 37 \\
\hline CM-2 & BA & 27 Feb 03 & 1 Mar 03 & 27 Apr 03 & 59 & 0 & 3 & 5 & 10 & 19 & 29 & 3 & 69 \\
\hline CM-3 & LS & 2 Mar 03 & 9 Mar 03 & 10 Jun 03 & 100 & 1 & 2 & 11 & 9 & 18 & 46 & 5 & 92 \\
\hline CM-4 & LS & 2 Mar 03 & 2 Mar 03 & 29 Apr 03 & 61 & 2 & 6 & 29 & 26 & 44 & 67 & 10 & 184 \\
\hline CM-5 & LS & 1 Apr 05 & 2 Apr 05 & 2 Jun 05 & 62 & 1 & 8 & 9 & 14 & 12 & 30 & 2 & 76 \\
\hline CM-6 & QP & 8 Apr 05 & 10 Apr 05 & 11 May 05 & 33 & 0 & 1 & 9 & 9 & 6 & 14 & 5 & 44 \\
\hline CM-7 & QP & 9 Apr 05 & 9 Apr 05 & 10 Jun 05 & 62 & 2 & 3 & 5 & 8 & 7 & 18 & 1 & 44 \\
\hline CM-8 & QP & 9 Apr 05 & 10 Apr 05 & 19 Jun 05 & 69 & 1 & 2 & 5 & 4 & 13 & 22 & 1 & 48 \\
\hline CM-9 & QP & 9 Apr 05 & 10 Apr 05 & 18 Jun 05 & 70 & 2 & 8 & 10 & 20 & 21 & 32 & 4 & 97 \\
\hline CM-10 & QP & 10 Apr 05 & 11 Apr 05 & 15 Jun 05 & 65 & 3 & 6 & 5 & 2 & 15 & 26 & 0 & 57 \\
\hline CM-11 & QP & 10 Apr 05 & 11 Apr 05 & 20 Jun 05 & 67 & 0 & 2 & 4 & 4 & 8 & 15 & 1 & 34 \\
\hline CM-12 & BA & 11 Apr 05 & 11 Apr 05 & 18 Jul 05 & 108 & 3 & 6 & 11 & 7 & 36 & 55 & 4 & 122 \\
\hline Total & & & & & 807 & 15 & 48 & 107 & 119 & 208 & 370 & 37 & 904 \\
\hline
\end{tabular}

Editorial responsibility: Brendan Godley (Editor-in-Chief), University of Exeter, Cornwall Campus, UK
Submitted: June 26, 2007; Accepted: October 31, 2007 Proofs received from author(s): November 27, 2007 